intensity of lines of the higher quantum numbers and compared it with Urey's correcting factor. That will account partly for the result expressed in terms of the parameter, $\mathrm{T}$, as indicating a lower temperature.

Prof. Lindemann supported the view that the future of eclipse work lies with photometry rather than with the determination of wave-lengths. In discussing the continuous light, the possibility of light-scattering in the instrument should be borne in mind. He would like to see a negative temperature gradient in the sun, such as might fit the demands of convective equilibrium.

\section{Dopes and Detonation.}

WE have received a copy of the Air Ministry Reports and Memoranda, No. xor3, by H. L. Callendar, R. O. King, and C. J. Sims, published by H.M. Stationery Office. The primary object of the investigation which is described was the determination of the physical actions that delay or prevent detonation in the cylinder of an internal combustion engine.

The addition to petrol of non-detonating fuels, such as benzene, has long been familiar as a means of checking the onset of "pinking' in a high-compression engine. In the case of benzene a large addition is required; alcohol and toluene are more effective than benzene by about 50 per cent., though they still appear to act mainly by dilution of the original fuel.

There are, however, other classes of substances, many times more effective than toluene, the action of which cannot be explained by dilution. Thus, in the case of lead ethide, the addition of 0.25 per cent. by volume is nearly as effective as roo per cent. of toluene. Nickel carbonyl shows a similar order of effectiveness.

The action of such 'dopes ' must evidently depend on some specific property requiring further investigation. It has been shown that the heavier paraffins, on account of their high critical temperatures combined with low critical pressures, are exceptionally liable to persist in the form of nuclear drops, which serve as foci of simultaneous ignition by compression owing to their low ignition temperature. The marked effect of pressure in promoting detonation is explained by the rapid increase of nuclear condensation with increased density of charge. The action of a dope in delaying detonation is to 'infect' the nuclear drops in such a way as to delay their ignition. The fact that these drops form a small percentage of the whole mixture helps to explain the possibility of a relatively small quantity of the dope being effective. It has been shown that lead ethyl and nickel carbonyl, two of the most effective metallic dopes, when mixed with petrol residues, decompose rapidly at temperatures above $200^{\circ}$ C., depositing a film of metal on the surface of the liquid. This metallic film would tend to protect the nuclear drops from oxidation, and would help to keep down their temperature by reflecting radiation.

Organic dopes, such as methylaniline and xylidine, have the advantage that much higher compression ratios can be employed than in the case of metallic dopes without risk of fouling the engine with deleterious deposits. On the other hand, much larger quantities are required than in the case of lead ethide. Organic dopes probably act mainly by the dilution of the nuclear drops, which results in a rise in the ignition temperature; but the chemical reactions which may occur are very complicated and require further investigation.

\section{University and Educational Intelligence.}

CAMBRIDGE.-Honorary degrees are to be offered to the Maharajadhiraja Bahadur of Burdwan, the Right Hon. W. L. Mackenzie King (Prime Minister of the Dominion of Canada), the Right Hon. J. G. Coates (Prime Minister of the Dominion of New Zealand), and to Mr. W. T. Cosgrave (President of the Executive Council of the Irish Free State)

Amongst those elected to the Council of the Senate are Sir H. K. Anderson, Dr. T. C. Fitzpatrick, Prof. A. C. Seward, Mr. T. Knox Shaw, and Mr. F. J. M. Stratton. Mr. R. E. Priestley, Clare College, assistant registrary, has been elected secretary of the general board of the faculties, a body that is to be elected for the first time on November 30.

Mr. W. H. Florey, lately John Lucas Walker Student and Rockefeller Research Fellow, has been elected to a fellowship at Gonville and Caius College.

Manchester.-The Council has made the following appointments: Dr. William Susman, to be lecturer in morbid anatomy and histology; Mr. C. J. Polson, to be assistant lecturer in chemical pathology; $\mathrm{Mr}$. A. M. Downie, to be assistant lecturer in bacteriology Dr. F. A. Mason, to be lecturer in tinctorial chemistry and dyestuffs; Mr. Arthur Riley, to be assistant lecturer in textile engineering; Mr. F. W. Bailey, lecturer in papermaking.

Dr. Ivar Waller has been awarded an honorary research fellowship in physics.

Dr. James A. Bowie has been appointed Director of the Department of Industrial Administration in the Manchester College of Technology. After the War, Dr. Bowie was appointed lecturer at the College, where he devoted his attention to industrial relations with special reference to problems of wages, profitsharing, and copartnership.

THE Universities of South Africa form the subject of an article by Prof. H. Clement Notcutt, of the University of Stellenbosch, in the October number of the University Bulletin (issued by the Association of University Teachers). It is pointed out that whereas the Act of Parliament which brought the Union into existence provided that the English and Dutch languages should both be "official," Afrikaans, which differs from the Dutch of Holland both in vocabulary and in syntax and is the home language of a large part of the inhabitants of Dutch descent has recently been given by Parliament the same status. Consequently there are now three official languages. In the schools, English and Afrikaans are taught with the intention that all children of European descent growing up in the country shall have an adequate knowledge of both languages, but there is an ever-present danger of their failing to acquire the power of using either with that exactness which is necessary for clear thinking. Prof. Notcutt might have added that the prestige won for Afrikaans has reacted unfavourably on the position of Dutch, and a movement inspired largely by enthusiasm for maintaining the Netherlands connexion and cherishing the traditions handed down from the original Dutch settlers is in fact tending to estrangement, for the Dutchmen of Holland cannot, generally speaking, find time to learn Afrikaans, nor can the Afrikanders spare for Dutch so much time as they could before Afrikaans became a literary and official language. It is estimated that a higher proportion of the white population is attending college or university than in Great Britain or any of the other British Dominions. A noteworthy characteristic of South African university students is their devotion to sports, in which respect they resemble the students of Oxford and Cambridge rather than those of the other English universities. 